\title{
紅茶製造における冷凍萎调茶葉の保存とその利用
}

\author{
カネトウ三浦園* \\ 川口茜 \\ 株式会社 新井園本店** \\ 佐 藤皓杜 \\ 山啓製茶株式会社 \\ 川野翼 \\ 農研機構果樹茶業研究部門* \\ 田村保晃 - 池田奈実子 ${ }^{\dagger}$
}

（2018年 2 月 11 日受理）

\section{Frozen Storage of Tea Leaves after Withering for Use in Black Tea Processing}

\author{
Akane Kawaguchi \\ Kaneto Miuraen \\ Hiroto Sato \\ Araien Honten, Inc. \\ Tubasa Kawano \\ Yamakei-seicha Co. Ltd \\ Yasuaki Tamura and Namiko Ikeda \\ Institute of Fruit Tree and Tea Science, NARO
}

Summary

Tea leaves that have been frozen and stored after steaming are generally used for processing of hand-rolled Japanese green tea (Temomi). However, there has not been a useful method for long-term storage of tea leaves for black tea processing. We stored withered tea leaves for period up to 5 months at $-20{ }^{\circ} \mathrm{C}$. Tea shoots of the cultivar Benifuki grown in a field of Kanaya Branch Station, NARO Institute of Fruit Tree and Tea Science, were used for materials. They were plucked by a riding-type plucking machine in the first crop season and second crop season. They were withered in a fresh tea leaf container. Fresh leaf weights were reduced by forty and thirty percent at the end of the withering process in first crop season and second crop season, respectively. The withered tea leaves were packed in 5-layered laminated film pouches. The pouches were vacuumed, filled with nitrogen, frozen quickly at $-30{ }^{\circ} \mathrm{C}$, and preserved at $-20{ }^{\circ} \mathrm{C}$. The frozen tea leaves were defrosted in a refrigerator overnight before

\footnotetext{
* $\quad$ \%428-0035 静岡県島田市切山1591-15

** $\quad \overline{4} 436-0005$ 静岡県掛川市伊達方323-1

*** 厂359-1141 埼玉県所沢市小手指町1-15-5

**** \%428-8501 静岡県島田市金谷猪土居2769

$\dagger \quad$ Corresponding author : namiko@affrc.go.jp
} 
rolling. Rolling and subsequent processes were carried out just after finishing the withering process and after frozen storage for 1 month, 3 months, and 5 months. Since there were no water drops on the unfrozen tea leaves, there was no inconvenience in the following processes. The quality of the tea was evaluated by a sensory test with 9 panels. There was no difference between the score for the tea produced just after withering and the scores for the tea produced with tea leaves that had been frozen for 1, 3 and 5 months. We won the silver award at Owari-Asahi Black Tea Competition for tea made with tea leaves that were plucked in the first flush season and frozen for 3 months. It was clarified that it is possible to produce a good-quality black tea with tea leaves that are frozen after withering.

Key Words : Camellia sinensis, black tea, withering, frozen storage

キーワード : チャ, 紅茶, 萎调, 冷凍保存

\section{1 緒 言}

茶に関するイベントにおいて, 製茶実演や体験は人気 を集め, 農研機構金谷茶業研究拠点の一般公開において も，最も人気があるコーナーである。紅茶は緑茶より香 りが強く, 製茶中の甘い香りが顧客を引き寄せ，消費者 に製造工程を理解してもらう手助けとなる。

しかし，日本の露地栽培では，年間の約半分しか新芽 を収穫することはできない。チャ新芽の生育期間中であ っても, 新芽の伸びは栽培管理だけでなく, 気象条件に 影響されるため, 開催日に適した原料を準備するのは容 易ではない。また，生産者主催のイベントは新芽が生育 を停止した農閑期に行われることが多い。したがって年 間を通して実演や体験を行うためには, 原料の保存が必 要である。

煎茶製造においては，摘採した新芽を蒸熱処理後，冷 凍保存する技術が確立され ${ }^{1)}$, 様々なイベントや手揉み 技術の向上に活用されている。紅茶も同様に原料を冷凍 保存できるのであれば，任意の時期の製造実演や体験が 可能になると考えられる。

そこで本試験では, 萎调後冷凍保存した紅茶の製造試 験を行い, 萎凋後の生葉は, 解凍した後に通常通り製茶 できるのか，また冷凍保存期間の違いが紅茶の品質に及 ぼす影響について検討した。

\section{2 材料及び方法}

\section{1 茶葉の摘採}

一番茶の摘採は，2016年 5 月 4 日 14 時30分から 14 時 40
分に行った。農研機構果樹茶業研究部門金谷茶業研究 拠点（静岡県島田市）内の戋場のチャ品種 ‘べにふうき’ の新芽を, 乗用型摘採機（カワサキ機工株式会社 KJ4） を用いて一芯三〜四葉で摘採した。天気は晴れ, 気温 $25{ }^{\circ} \mathrm{C}$, 湿度 $41 \%$ \%あった。

二番茶の摘採は, 2016 年 6 月 21 日 9 時 24 分から 9 時 35 分に行った。围場, 摘採機は一番茶新芽と同様のものを 用いた。天気は晴れ, 気温 $24{ }^{\circ} \mathrm{C}$, 湿度 $83 \%$ \%でった。

\section{2 萎调}

一番茶, 二番茶とも農研機構果樹茶業研究部門金谷茶 業研究拠点内の緑茶工場で萎调を行った。萎调には, 生 葉コンテナ $300 k$ 機（カワサキ機工株式会社）を使用した。 コンテナは生葉投入直後から 3 時間連続送風, その後は 30分おきに送風と停止を繰り返した。加湿器は使用しな かった。萎调の目安は重量を基準として, 一番茶は, 茶 葉投入直後の重量から 40 \%隇少するまで, 二番茶は生 葉の含水率が一番茶と比べて低いため, 投入直後の重量 から 30 \%減少するまでとした。

一番茶製造では, 2016年 5 月 5 日 15 時10分に, 摘採し た茶葉 $47 \mathrm{~kg}$ を生葉コンテナに投入して萎调を開始した。 摘採した茶葉を厚さ約 $3 \mathrm{~cm}$ になるように均一に敷き詰め た。萎调開始直後と 4 時後, 8 時間後の 3 回摚汼を行っ た。 5 月 6 日 8 時に生葉コンテナの送風を停止し， 9 時 頃に茶葉の重量が萎调開始時から $40 \%$ 減少したため, 萎 调を終了した（図 1 )。萎调時の緑茶工場内の平均気温 は $21{ }^{\circ} \mathrm{C}$, 平均湿度は5 $2 \%$, 生葉コンテナ内の平均気温 は $19.1{ }^{\circ} \mathrm{C}$, 平均湿度は $91.3 \%$ \%゙った。天気は 5 月 5 日 14時から 5 月 6 日の 8 時ごろまで晴れていて, 萎调終了 後の 5 月 6 日 9 時ごろから是り始めた。 


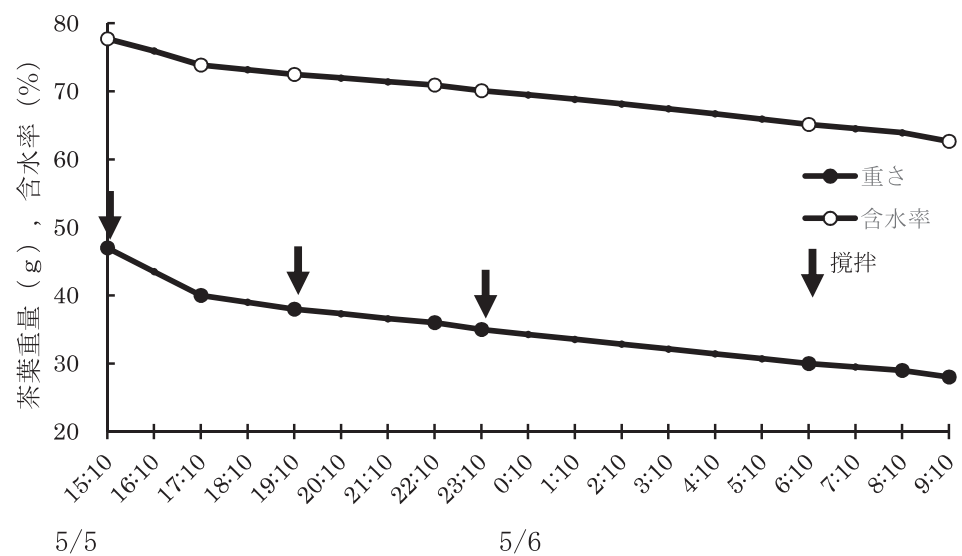

図 1 一番茶期の萎调における茶葉重量及び含水率の変化

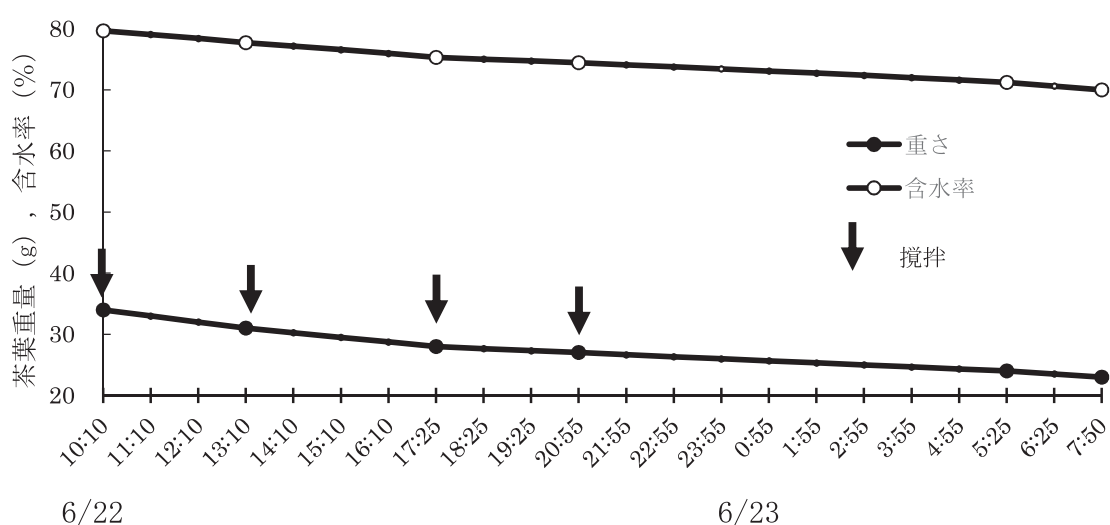

図 2 二番茶期の萎凋における茶葉重量及び含水率の変化

二番茶製造では，2016年 6 月 22 日10時10分に，摘採し た茶葉 $34 \mathrm{~kg}$ を生葉コンテナに投入して萎调を開始した。 摘採した茶葉を厚さ約 $3 \mathrm{~cm}$ になるように均一に敷き詰め た。萎调開始直後と， 3 時間後， 6 時間後， 9 時間後の 4 回，撹挥を行った。 6 月23日 7 時50分ごろに重量が 萎调開始時から $30 \%$ 減の $23 \mathrm{~kg}$ に達したので萎调を終了 した（図 2 ）。萎调時の緑茶工場内の平均気温は $23.3{ }^{\circ} \mathrm{C}$, 平均湿度は $90 \%$ であった。天気は 6 月 22 日から 23 日に かけて晴れていた。

\section{3 冷凍保存}

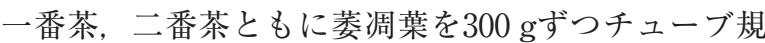
格袋UT-2535（厚さ70 $\mu \mathrm{m} \times$ 横 $250 \mathrm{~mm} \times$ 縦 $350 \mathrm{~mm}$, ク リロン化成株式会社）に入れて小分けし，卓上型真空ガ ス包装機 $\mathrm{M}-1$ （友和産業株式会社）を用いて，真空にし た後，窒素充填を行った。真空時間は13秒，窒素充填時 間は 5 秒とした。

冷凍保存は, 前処理として窒素封入後の袋を $-30{ }^{\circ} \mathrm{C}$ の低温恒温槽PU-2FT・P（タバイエスペック株式会社）
に40分入れ，急速な冷凍処理を行った。その後, 冷凍庫 (サンデン株式会社) に入れ， $-20{ }^{\circ} \mathrm{C}$ 以下の冷凍庫内で 1 〜 ケ月保存した。

\section{4 紅茶製造}

一番茶，二番茶とも萎调した茶葉を用いて，当日（摘 採日の翌日の萎调終了後), 1 ケ月後, 3 ケ月後, 5 ケ 月後に金谷茶業研究拠点内の新製品開発実験棟で行った (表 1 )。製造の反復は 2 とした。 1 回分の製造に, 生葉 換算で $4 \mathrm{~kg}$ 分の萎凋後冷凍した茶葉を用いた。冷凍保存 した茶葉は製造日前日に冷凍庫から室温 $5 \sim 6{ }^{\circ} \mathrm{C}$ の冷蔵 庫へ移し，14時間から16時間解凍を行った。開封は製造 直前に行った。

揉捻は，紅茶用少量揉捻機（伊達製作所，新鮮葉を基 準として $4 \mathrm{~kg}$ 用）を用いて行った。工程は，5分間蓋を 上げて熱を逃がす作業 5 回，10分間圧力をかけて揉み込 む作業 4 回を交互に行った。合計の揉捻時間は65分間で あった。

発酵は，発酵室内で行った。揉捻後の茶葉を発酵箱に 
表 1 紅茶製造法と環境条件

\begin{tabular}{lcccc}
\hline 茶期・製造日 & 温度 $\left({ }^{\circ} \mathrm{C}\right)$ & 湿度 $(\%)$ & 天気 & その他 \\
\hline 一番茶 & & & & \\
当日 $(5 / 6)$ & 21 & 42 & 曇のち雨 & \\
1 ヶ月後 $(6 / 7)$ & 23 & 75 & 雨 & \\
3 ヶ月後 $(7 / 28)$ & 25 & 84 & 曇のち晴 & 青臭さが抜けず発酵を30分延長 \\
5 ケ月後 $(9 / 30)$ & 24 & 84 & 晴 & \\
二番茶 & & & & \\
当日 $(6 / 23)$ & 25 & 84 & 雨のち晴 & \\
1 ケ月後 $(7 / 28)$ & 25 & 84 & 曇のち晴 & \\
3 ケ月後 $(9 / 30)$ & 23 & 75 & 量 & \\
5 ケ月後 $(11 / 28)$ & 14 & 78 & 晴 & 茶温が上がらず, 最初の20分揉捻 \\
\hline
\end{tabular}

約 $7 \mathrm{~cm}$ の厚みになるように敷いた。発酵室の壁や床に水 を撒き, 濡れた布巾を発酵箱の縁にかけて湿度を保った。 発酵時間は 2 時間 30 分であった。発酵室の室温は $26^{\circ} \mathrm{C}$, 湿度は $100 \%$ であった。

乾燥は透気乾燥機 $50 \mathrm{~K}$ （カワサキ機工株式会社）を用 いて行った。あらかじめ $105{ }^{\circ} \mathrm{C}$ の熱風で温めておいた棚 に発酵後の茶葉を入れて，5分間発酵止めを行い，その 後 $60^{\circ} \mathrm{C}$ の熱風温度で55分間, 合計 60 分間乾燥を行った。

試料はチャック付アルミラミネート袋に入れて, 冷凍 萎调葉の保存と同じ機械を用いて, 真空, 窒素封入を行 い, $13{ }^{\circ} \mathrm{C}$ で審査まで保存した。

\section{5 官能審査}

2016年12月14日に金谷研究拠点内の審査室で，官能審 査による品質変化の評価を行った。試料は本試験で作成 した一番茶 8 点（試料番号 $1 \sim 8$ ), 二番茶 8 点（試料 番号 9 〜 16) を用いた。比較試料として金谷研究拠点内 のチャ品種 ‘べにふうき’の新芽を手摘みした原料を用 いて2016年 5 月 6 日に $4 \mathrm{~kg}$ 用少量揉捻機で揉捻し， 1 時 間（試料番号17）あるいは 2 時間（試料番号18）発酵さ せた紅茶, 2014年 8 月にウンカに加害されたチャ品種 ‘べ にふうき’の新芽を手摘みした原料を用いて $4 \mathrm{~kg}$ 用少量 揉捻機で揉捻した紅茶（試料番号19），G製茶の紅茶（品 種 ‘まきのはらわせ’，“とよか’のブレンド, 試料番号20) 及びY紅茶(品種 “べにふうき’, 試料番号21)を用いた(表 3 )。国産紅茶グランプリ2016年で, 試料番号20はグラ ンプリ，試料番号 21 は審査員長賞を受賞している。

審査員は, 武田善行博士, 職員 3 名, 契約職員 1 名, 依頼研究員 1 名, 講習生 1 名, 学生 2 名の合計 9 名で行 った。容量 $140 \mathrm{ml}$ の英国式審査茶碗を用い, 茶葉 $3 \mathrm{~g}$ を $100{ }^{\circ} \mathrm{C}$ の熱湯で 4 分間浸出した。試料の内容は開示した。 審査項目は, 外観, 殼色, 香気, 水色, 滋味で, 5 点満 点で評価した。また，審査員の好き嫌いについての評価
を好き 3 点, 普通 2 点, 嫌い 1 点の 3 段階で行った。多 重比較検定には, 統計ソフトゥエアSTATISTICA '98 Editionを用いた。

\section{6 紅茶フェスティバルin尾張旭の国産紅茶グ ランプリ2016への出品}

一番茶の当日，1 ケ月後，3 月月後に製造した紅茶を， 紅茶フェスティバルin尾張旭の国産紅茶グランプリ 2016 へ出品した。予選は, 2016年10月 3 日に専門家の審査員 5 名,一般審査員 5 名, 計 10 名が， 1 : 好き， 2 :普通， 3 : 嫌いで個別に評価を行い, 合計值を求める方法で行われ た。最低が10点, 最高が30点で, 得点が少ない方が好み の紅茶となる。決勝へ進出した紅茶以外については, 予 選終了後, ウエッブサイトへ点数が公表された。1出品 者のグランプリへの応募点数は制限されていないが, 決 勝進出については 1 出品者 1 点である。決勝は 2016 年 10 月23日に, 愛知県尾張旭市のスカイワードあさひで, 専 門審査員10名と一般審査員100名によって審査が行われた。

\section{3 結 果}

一番茶, 二番茶とも生葉コンテナを用いて萎调を行っ た。重量減の目標は, 一番茶が二番茶より含水率が高い と想定して, 一番茶40％減，二番茶30％減としたが, 摘採茶葉の湿量基準の含水率は一番茶が $77.8 \%$, 二番茶 が79.7\%で, 二番茶の方が高かった。萎调終了時の含水 率は一番茶が $62.6 \%$ （乾量基準含水率 $167.6 \%$ ), 二番茶 が70.0\%（乾量基準含水率 $233.1 \%$ ）であった。萎调開 始から 9 時間以内の含水率が高い時に，3〜4時間おき に数回, 擋拌を行うことによって, 速やかに, かつ均一 に含水率を減らすことができた（図 1 , 図 2 )。

萎调後冷凍した茶葉は煎茶用の蒸し葉より含水率が低 く, 解凍時に結露しなかったため扱いやすく, 解凍後速 
やかに製茶を開始することができた。解凍して少し冷た さが残る状態で揉捻を開始した。

官能審査結果について, 試料, 審査員を要因とする繰 り返しなしの二元配置分散分析を行った（表 2 )。すべ ての審査項目において，試料について差が認められたの で，テューキーの多重比較検定を行った。試料番号 1

表 2 官能審査結果についての分散分析によるF值

\begin{tabular}{llllll}
\hline & 外観 & 殼色 & 香気 & 水色 & 滋味 \\
\hline 試料 & $26.28^{* *}$ & $9.39^{* *}$ & $2.91^{* *}$ & $5.84^{* *}$ & $1.35^{* *}$ \\
審査員 & $13.62^{* *}$ & $6.08^{* *}$ & $5.65^{* *}$ & $15.00^{* *}$ & 4.87 \\
\hline
\end{tabular}

**: F検定の結果, $1 \%$ 水準で有意.
8 の一番茶の 8 点は, 試料間で審査項目すべてにおいて 平均值に差が認められなかった。試料番号 9 〜 16の二番 茶の 8 点も, すべての審査項目において平均值に差が認 められなかった。一番茶, 二番茶とも当日製造した紅茶 と 1 ケ月後， 3 ケ月後，5 ケ月後に製造した紅茶との間 には製茶品質に差がないといえた（表 3 )。水色は, 一 番茶はオレンジ色, 二番茶は一番茶より赤みが強かった。 一番茶は二番茶より官能審査の合計点の平均値, 好みの 平均值とも高かった（図 3 )。

紅茶フェスティバルin尾張旭の国産紅茶グランプリ 2016での結果は, 一番茶の 3 ケ月間冷凍保存後製造した

表 3 紅茶の官能審査結果

\begin{tabular}{|c|c|c|c|c|c|c|c|c|c|c|c|}
\hline \multicolumn{2}{|c|}{ 試料番号 } & \multicolumn{2}{|c|}{ 外観 } & \multicolumn{2}{|r|}{ 殼色 } & \multicolumn{2}{|r|}{ 香気 } & \multicolumn{2}{|r|}{ 水色 } & \multicolumn{2}{|r|}{ 滋味 } \\
\hline 1 & 一番茶当日 I & 3.7 & def & 3.2 & $a b$ & 3.7 & $a b$ & 3.7 & $\mathrm{ace}$ & 4.3 & $\mathrm{f}$ \\
\hline 2 & 一番茶当日 II & 3.0 & $\operatorname{def}$ & 3.1 & $\mathrm{ab}$ & 3.7 & $a b$ & 3.6 & $\mathrm{a} \mathrm{c} \mathrm{e}$ & 4.1 & cdef \\
\hline 3 & 一番茶 1 ケ月後 I & 3.3 & cde & 2.9 & a & 3.3 & $a b$ & 3.4 & $\mathrm{a} c \mathrm{e}$ & 3.3 & abcdef \\
\hline 4 & 一番茶 1 ケ月後 II & 3.2 & bcde & 3.1 & $a b$ & 3.1 & $a b$ & 4.0 & b de & 3.2 & abcdef \\
\hline 5 & 一番茶 3 ケ月後 I & 3.2 & bcde & 2.9 & $\mathrm{a}$ & 3.1 & $a b$ & 3.3 & $\mathrm{a} \mathrm{c} \mathrm{e}$ & 4.0 & cdef \\
\hline 6 & 一番茶 3 ケ月後 II & 3.1 & abcde & 2.8 & $\mathrm{a}$ & 3.0 & $\mathrm{ab}$ & 3.2 & a c e & 3.9 & cdef \\
\hline 7 & 一番茶 5 ヶ月後 I & 3.2 & bcde & 2.9 & $\mathrm{a}$ & 2.9 & $a b$ & 4.2 & $\mathrm{c} \mathrm{e}$ & 3.3 & abcdef \\
\hline 8 & 一番茶 5 ケ月後 II & 3.0 & abcd & 3.1 & $\mathrm{ab}$ & 3.0 & $a b$ & 4.2 & $\mathrm{c} \mathrm{e}$ & 3.3 & abcdef \\
\hline 9 & 二番茶当日 I & 2.9 & abcd & 3.2 & $\mathrm{ab}$ & 2.9 & $a b$ & 3.0 & a c & 2.7 & abcd \\
\hline 10 & 二番茶当日 II & 3.0 & abcd & 3.3 & $\mathrm{ab}$ & 2.8 & $\mathrm{a}$ & 3.6 & a c e & 2.6 & abc e \\
\hline 11 & 二番茶 1 ケ月後 I & 2.7 & abcd & 3.3 & $a b$ & 3.1 & $a b$ & 2.9 & $\mathrm{ac}$ & 2.9 & abcdef \\
\hline 12 & 二番茶 1 ケ月後 II & 2.9 & abcd & 3.1 & $a b$ & 3.0 & $a b$ & 2.7 & $\mathrm{abd}$ & 2.8 & abcdef \\
\hline 13 & 二番茶 3 ヶ月後 I & 2.4 & $a b c$ & 3.0 & a & 2.8 & $\mathrm{a}$ & 3.2 & a c e & 2.8 & abc e \\
\hline 14 & 二番茶 3 ヶ月後 II & 2.2 & $a b$ & 2.9 & a & 2.8 & $\mathrm{a}$ & 2.7 & $a b d$ & 2.0 & $\mathrm{a}$ \\
\hline 15 & 二番茶 5 ヶ月後 I & 2.1 & $\mathrm{a}$ & 2.8 & $\mathrm{a}$ & 2.8 & $\mathrm{a}$ & 3.6 & $\mathrm{a} \mathrm{c} \mathrm{e}$ & 2.4 & abcd \\
\hline 16 & 二番茶 5 ヶ月後 II & 2.2 & $a b$ & 2.8 & a & 2.9 & $a b$ & 2.6 & a & 2.4 & abcd \\
\hline 17 & 手摘み発酵 1 時間 & 4.6 & fg & 2.6 & $\mathrm{a}$ & 3.4 & $a b$ & 3.3 & $\mathrm{ace}$ & 3.3 & abcdef \\
\hline 18 & 手摘み発酵 2 時間 & 4.6 & $\mathrm{fg}$ & 2.6 & a & 3.9 & $a b$ & 3.2 & $\mathrm{ace}$ & 3.4 & abcdef \\
\hline 19 & 2014年二番茶 & 5.0 & $\mathrm{~g}$ & 4.9 & $\mathrm{c}$ & 4.4 & $\mathrm{~b}$ & 4.4 & $\mathrm{e}$ & 4.0 & def \\
\hline 20 & $\mathrm{G}$ 製茶 & 5.0 & $\mathrm{~g}$ & 5.0 & c & 4.2 & $a b$ & 3.2 & $\mathrm{a} \mathrm{c} \mathrm{e}$ & 4.2 & ef \\
\hline 21 & Y 紅茶 & 4.1 & efg & 4.3 & bc & 3.7 & $a b$ & 4.0 & bcde & 3.7 & def \\
\hline
\end{tabular}

Turkeyの多重比較検定の結果, 各審査項目の異なる英文字間には $5 \%$ 水準で有意差が認められる。

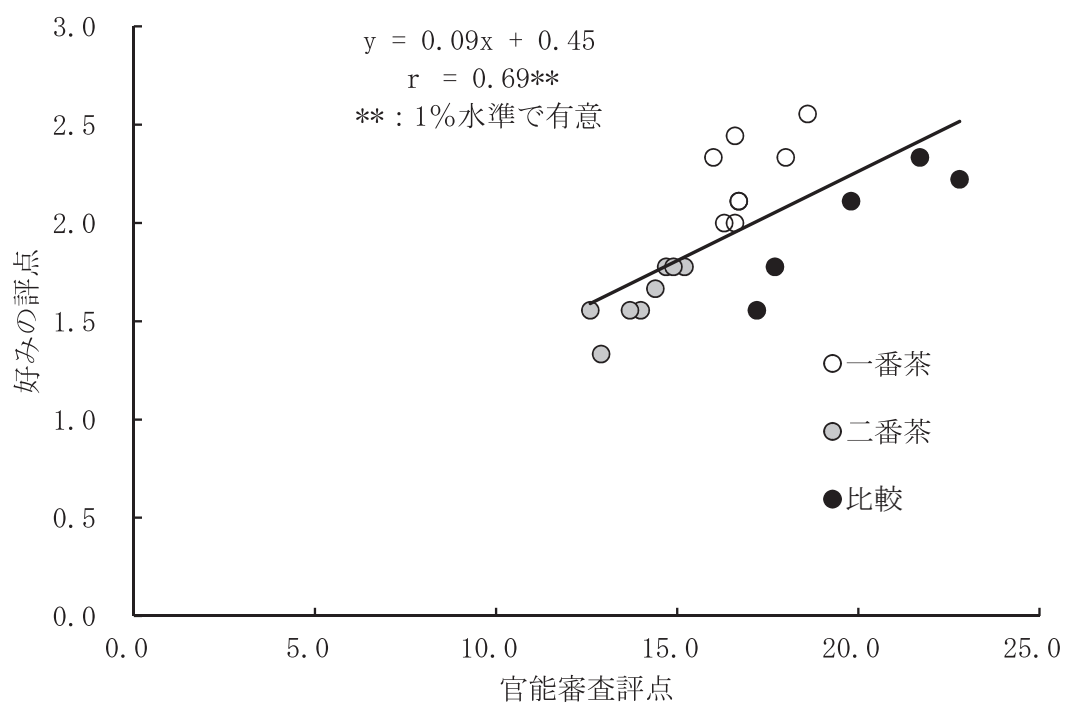

図 3 紅茶の官能審査の合計点と好みの関係 


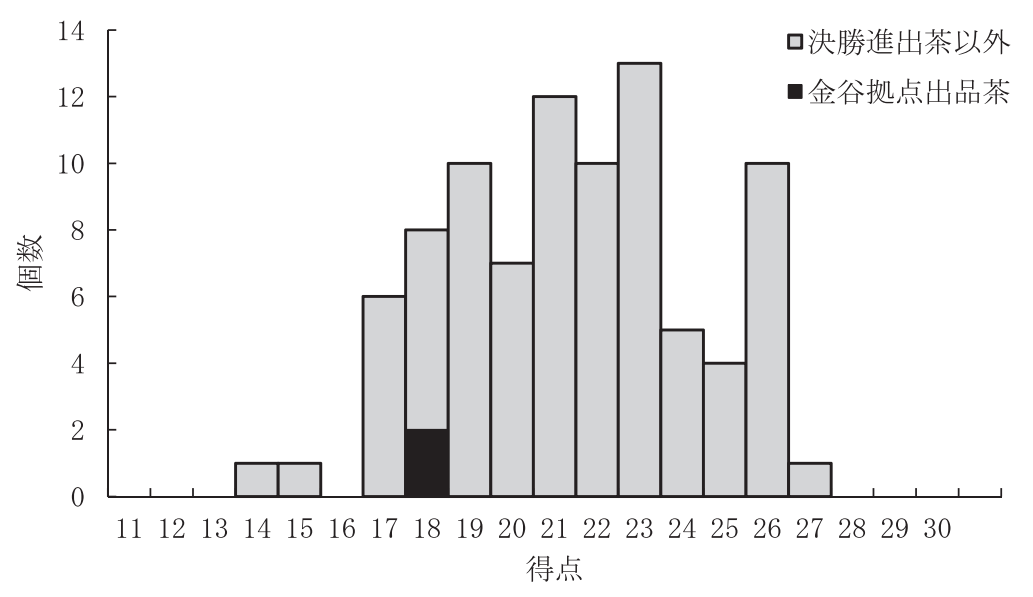

図 4 国産紅茶グランプリにおける決勝進出者を除く得点の分布

紅茶が銀賞を獲得した。入賞した紅茶については，予選 の点数は公表されないので不明である。当日製造した紅 茶と 1 ケ月後に製造した紅茶はどちらも18点で, 予選を 通過しなかった紅茶の中では上位であった（図 4)。

\section{4 考察}

一番茶，二番茶とも萎调終了後すぐに製茶した紅茶の 品質と, 冷凍保存後製茶した紅茶の品質との間には差は なかった。保存期間による差もなかった。尾張旭の国産 紅茶グランプリ2016の結果も，3 3 ケ月間冷凍保存後，製 茶した紅茶が入賞した。したがって，萎调後 5 ケ月後ま で冷凍保存しても品質は低下しないと考えられた。

尾張旭の国産紅茶グランプリ2016では，入賞は 1 出品 者 1 点と決まっているため, 14点から17点の紅茶の中に は入賞した出品者の紅茶が含まれると考えられるが，当 日製茶，1 月月後製茶の紅茶も18点で入賞した紅茶以外 では上位であった。萎调終了後当日に製茶した紅茶では なく，3 ケ月後に製茶した紅茶が入賞したのは，揉捻以 降の工程時の環境条件が当日より良かったからと考えら れるが，当日製茶， 1 ケ月後製茶の紅茶も入賞した紅茶 の品質と大きな差はなかったと考えられた。

萎调後の含水率の基準は，スリランカでは乾量基準で Hard witherが108.1 \%, Medium witherが122.2 \%, Soft witherが $138.1 \%$, Very soft witherが $233.3 \%$ である ${ }^{2)}$ 。 本試験における含水率は一番茶, 二番茶とも Soft wither からVery soft witherの間であった。二番茶の水色が濃 かったのは，含水率が高く，酵素反応が進んだためであ ると考えられる。萎调は新芽の含水率を減少させて加工 しやすくすると同時に，酵素活性を高める工程であり，
12〜18時間かけて行うことが必要である ${ }^{3)}$ 。専用の萎调 槽を用いて行うのが望ましいが, 現在の紅茶生産は 1 戸 当たりの生産規模が小さいので設備投資が難しく，既 存の設備を利用するのが現実的である。しかし, 熊本 県が奨励するような粗揉機を用いて含水率を急激に下 げる方法では, 紅茶特有の香りや味が形成されない ${ }^{4}$ 。 1950年代半ばの月刊誌「茶」には，粗揉機で含水率を減 少させることを戒める記事が繰り返し掲載されている が $^{5 \sim 8)}$ 紅茶の商業的な生産が途絶えて 40 年以上経過し, 茶の行政, 普及, 研究機関では知識や技術が伝承されて いない。本試験では緑茶用の生葉コンテナを用いても, 香気を発揚することができた。

緑茶用に蒸熱後冷凍した茶葉では, 解凍時に表面が結 露するため, 水滴を取り除かなければならない。しかし, 萎调葉の場合は冷凍しても, 細胞内の水が大きく成長す ることがないため, 細胞膜を壊すことがなく, 解凍して も結露せず, 茶葉の傷みが小さかった。また, 萎调後冷 凍した茶葉は, 解凍時に容易にほぐれてすぐに揉捻が可 能であった。

現在では蒸熱処理茶葉は数ヶ月以上保存されて, 煎茶 の手揉みの練習や競技会, イベントなどに活用されてい る。しかし緑茶用の蒸熱処理茶葉の冷凍試験では, $-20^{\circ} \mathrm{C}$ で 1 ケ月以上保存すると, 製茶した場合の官能審査の点 数が低下し, 品質劣化の指標であるアスコルビン酸含有 量も低下することが報告されている ${ }^{1)}$ 。この試験は1964 年から1966年に行われたので，当時は冷凍庫の性能が十 分でなかったため，1ヶ月以上の冷凍で品質が劣化した と考えられる。

吉田・松ケ谷（2014）は, 解凍方法について比較を行 い, $5{ }^{\circ} \mathrm{C}$ の低温で解凍した場合は, 当日製茶した場合や, 
流水で急速解凍した場合に比べて製茶品質が劣ると報告 している ${ }^{9)}$ 。しかし，本試験では， $5 \sim 6{ }^{\circ} \mathrm{C}$ の泠蔵庫内 に一晚静置して解凍したが，当日製茶したものと差が認 められなかった。本試験では真空・窒素封入したまま低 温で解凍したため, 急速解凍しなくても，酵素反応の再 開が抑えられて, 劣化が起こらなかったと考えられるが, 吉田・松ケ谷（2014）の試験とは品種，栽培条件，摘採 方法, 萎调の条件も異なるので, 急速解凍の必要性につ いては今後検討が必要である。

本試験では乗用型摘採機を用いて摘採した茶葉を用い た。比較試料の国産紅茶グランプリでグランプリを受賞 したNo.20のG製茶の紅茶や，No.19の2014年二番茶の外 観は満点で, No.20の水色を除き，他の審査項目もす心゙ て4点以上であった。しかしこれらの紅茶はウンカに加 害された芽を用いているため新芽の伸びが悪く，手摘み でないと大きく品質が低下する。一方，本試験の原料の ように，新芽の伸びと揃いがよい原料を用いるのであれ ば，機械摘採でも，コンテストへ入賞できるような良質 な紅茶を製造できることが明らかになった。

2016年の日本における紅茶の消費量は 15,680 tで，最 近は減少している。全消費量に占めるリーフティーの割 合も減少し，2015年は $8.4 \%$ に過ぎない ${ }^{10)}$ 。紅茶のリー フを見たことがなかったり，紅茶が緑茶と同じチャの木 の新芽を用いてつくられることを知らない日本人も多 い。煎茶では，茶作りイベントのための簡易小型焙炉も 考案されているが ${ }^{11)}$, 紅茶の製造体験では焙炉は必要な く,ザルとホットプレートのような家庭用の道具だけで 行うことができる。紅茶の製造体験や製茶実演では製造 工程での香りや色の変化や, 揉捻中の茶葉の温度が酵素 反応で上昇することを五感で体験できる。冷凍葉を用い ることで, 体験や実演を数多く行うことによって, 紅茶 への理解を深め, 消費拡大につなげることが期待できる。

本試験の結果は, 紅茶製造に打いて萎调後冷凍するこ とが可能であることを示したとともに，機械摘採した原 料を, 生葉コンテナを用いて萎调を行っても, コンテス トで入賞できるレベルの紅茶を製造できることを示し た。小規模な現在の日本の紅茶生産において有益な情報 であると考えられる。

\section{5 摘 要}

材料は農研機構果樹茶業研究部門金谷茶業研究拠点内 の戋場の ‘゙にふうき’を用い，一番茶新芽及び二番茶 新芽を乗用型摘採機を用いて摘採した。萎调は生葉コン
テナを用いて，一番茶は重量が40 \% 減するまで, 二番 茶は重量30％減少するまで行った。チューブ規格袋に入 れて小分けし, 卓上型真空ガス包装機を用いて, 真空に した後, 窒素充填を行った。窒素封入後の袋を $-30{ }^{\circ} \mathrm{C}$ で40分間急速冷凍を行った後, $-20{ }^{\circ} \mathrm{C} て ゙$ 保存した。解 凍は，前日夕方から冷蔵庫内で行った。製茶は当日（摘 採日の翌日の萎调終了後), 摘採から 1 ケ月後, 3 ヶ月 後, 5 ケ月後に行った。一番茶, 二番茶とも, 水分が茶 葉の表面に付くことはなく, 通常通り製茶を行うことが できた。審査員 9 名による官能審査を行った結果，一番 茶，二番茶とも当日と 1 ケ月間， 3 ケ月間， 5 ケ月間保 存後製造したものとの間に差はなかった。一番茶の萎调 葉を 3 ケ月間保存した原料を用いて製造した紅茶が尾張 旭の国産紅茶グランプリで銀賞を獲得したことで，冷凍 保存した原料を用いても良質な紅茶を製造できることが 明らかになった。

\section{6 謝 辞}

比較として用いた試料の一部を提供いただき，本試験 への助言及び官能審査にご協力いただいた武田善行博士 に深謝する。また茶園の管理や茶葉を提供していただい た農研機構果樹茶業部門の野中邦彦前業務第二科長及び 業務第二科の関義晃氏，伊藤康博氏，陶山堸氏，松本政 明氏に深謝する。

\section{7 引用文献}

1 ) 古谷弘三・岩堀源五郎・田中伸三（1968）：蒸熱処理茶葉の凍 結貯蔵中の变質。茶業技術研究， $36 ， 42-51$.

2 ) Samaraweera, D. S. A. (2008) : Moisture content. Handbook of Tea, Tea Research Association of Sri Lanka, pp.266-277.

3 ）武田善行 (2016)：発酵茶の製造法. 図解 茶生産の最新技術 一製造編一, 公益社団法人静岡県茶業会議所, pp.142-156.

4 ）島田雅伸（2006）：緑茶用品種を用いた簡易紅茶製造法. 熊本 県農業研究成果情報, 256.

5 )「茶」編集部 (1954): 玉緑茶, 紅茶の生産をめぐって一業界 の希望は指導と研究一。茶, $7(10), 20-23$.

6 ）上野健二 (1955)：紅茶製造上の問題点. 茶， 8(2)，18-21.

7 ) 足立東平 (1955)：これからの紅茶生産はこうしたい. 茶, 8(2), 13-17.

8 ）杉山春喜智（1955）：紅茶の製造について。茶，8(7)，24-27.

9 ) 吉田充希・松ケ谷祐三（2014）：伊勢茶を活用した機能性・高 付加価值商品等の開発. 三重県研究成果情報。

10）日本紅茶協会 (2017) : 紅茶の種類別生産量の推移. 紅茶統計, 日本紅茶協会, p.25.

11）宮本大輔・前川寛之（2014）：簡易小型焙炉の考案と茶作りイ ベントへの利用．奈良総農セ研報，45，21-23. 